\title{
A Visual Asian American Diaspora: Belle Yang's Hannah is My Name (2004) and Guene Luen Yang's American Born Chinese (2006)
}

\author{
Marwa Essam Eldin Fahmi ${ }^{1}$ \\ ${ }^{1}$ College of Foreign Languages \& Translation, MISR University for Science \& Technology, Giza, Egypt \\ Correspondence: Marwa Essam Eldin Fahmi, College of Foreign Languages \& Translation, MISR University for \\ Science \& Technology, Giza, Egypt. E-mail: drmarwaalkhayat@yahoo.com
}

Received: March 15, 2016 Accepted: March 30, 2016 Online Published: April 28, 2016

doi:10.5539/ells.v6n2p43 URL: http://dx.doi.org/10.5539/ells.v6n2p43

\begin{abstract}
The current study aims at theorizing the question of identity within the framework of postcolonial studies in two visual narratives: Belle Yang's Hannah is My Name (2004) and Guene Luen Yang's American Born Chinese (2006). Asian American studies have recently interrogated identity marking a shift from ethnic nationalism to recognition of multiplicity. The study also seeks to counter Orientalist stereotypes in American literature through the analysis and examination of postcolonial Asian American Diaspora to highlight a number of questions: 1) How is the identity of the Asian immigrant's hybrid visually constructed? 2) How can Asian American visuals be addressed in non-white children's literature? 3) What nurtures the transnational imaginations of the authors/illustrators in question? 4) What are the ramifications of transnational perspectives on Asian American narratives? 5) What are the nature of belonging and citizenship? The questions are a vehicle to investigate the cultural and ethnic politics of Chinese American literature and to explore new forms of self-identification in American literary discourse. They also yield rich insights into how to practice multiculturalism. What draws the visual narratives in question together is their postcolonial theme of reformulated identity to unsettle dichotomies within Asian American community. Furthermore, the present study explores semiotic systems in terms of image syntax, gestural, spatial and iconic signs to examine the relation between the denotative context of the narrative text and the connotation of the visual text that creates polysemous illustrations and indefinite meaning-making.
\end{abstract}

Keywords: graphic novel, picture book, none-white children's literature, hybrid identity, Asian American diaspora

\section{Introduction}

"Yellow history is still the great yellow mystery"-(Chan, 1974, xxiv)

Immigration literature is geographically, socially and culturally shaped by various forms of racial interrelation. Asian American literature exhibits a deep sense of hybridity immigrant's past and current American social reality. Asian American means "Filipino-, Chinese-, and Japanese-Americans, American born and raised" (Chan et al., 1974, vii) and as a term, it was coined in the late 1960s in California by students who modeled their demands for ethnic empowerment in the civil rights movement in order to "possibly claim a lawful right as representative citizens and reconstruct their own "collective identities"' (Chae, 2008, x).

Asian immigration to the United States has taken place since the mid-nineteenth century and Asian immigration history since its inception till the mid-twentieth century is characterized by prejudice, violence, exclusion and deportation. Stereotyped images define Chinese immigrants as culturally and racially "Other" and suppress their specific differences in class, gender, and cultural experience. Robert Lee-in Orientals: Asian Americans in Popular Culture (1999) - summaries six major stereotypes against Asian Americans: "the pollutant, the coolie, the deviant, the yellow peril, the model minority and the gook" (Lee, 1999, p. 8) that correspond to specific stages in Asian American history. Yet, the "Model Minority" myth homogenizes Asians by constructing them as the most successfully assimilated minority group. They were willing to work hard at even the menial jobs offered to them. The "Model Minority" discourse seems to praise Asian Americans for succeeding economically in the US and for becoming assimilated into the mainstream.

The current study aims at theorizing the question of identity within the framework of postcolonial studies in two visual narratives: Belle Yang's Hannah is My Name (2004) and Guene Luen Yang's American Born Chinese 
(2006). Asian American studies have recently interrogated identity marking a shift from ethnic nationalism to recognition of multiplicity. The study also seeks to counter Orientalist stereotypes in American literature through the analysis and examination of postcolonial Asian American Diaspora to highlight a number of questions:

1) How is the identity of the Asian immigrant's hybrid constructed visually?

2) How can Asian American visuals be addressed in non-white children's literature?

3) What nurtures the transnational imaginations of the authors/illustrators in question?

4) What are the ramifications of transnational perspectives on Asian American narratives?

5) What are the nature of belonging and citizenship?

The questions are a vehicle to investigate the cultural and ethnic politics of Chinese American literature and to explore new forms of self-identification in American literary discourse. They also yield rich insights into how to practice multiculturalism. What draws the visual narratives in question together is their postcolonial theme of reformulated identity to unsettle dichotomies within Asian American community. Postcolonial theory provides a powerful approach to ethnic literatures significantly influenced by cultural domination of the United States. Elain Kim defines-in her "Preface" of the pioneering work American Literature: An Introduction to Writings and Their Social Context (1982)-Asian American Literature "as published creative writings in English by Americans of Chinese, Japanese, Korean and Filipino descent" (xi). In this sense, Asian American literary criticism - in a globalized context—tackles the formative concept of "home" and "self" in the immigrant's psyche.

\section{Postcolonial Asian American Diaspora}

The contention of this study is to probe postcolonial Asian American consciousness. In An Introduction to Postcolonial Theory (1997), Peter Childs and Patrick Williams define the Chinese community in the United States within the perspective of postcolonial theory (Childs \& Williams, 1997, pp. 10-13) to explore racial, ethnic and cultural identity that are crucial to the analysis of minority writing. In Imagining the Nation: Asian American Literature and Cultural Consent (1998), David Leiwei Li alludes to the surge in Asian immigration in the late nineteenth century that gave rise to a fear that was referred to as the "yellow peril". The phrase was commonly used in several newspapers such as The San Francisco Examiner and The New York Journal. Media representations of "yellow peril" expose the power relationship between the ruling elite and the ethnic minority: political caricatures of Chinese immigrants - for example-have depicted them as debased, deceitful and derogatory race prone to vice and illegalities. Li also refers to the shift of the political standpoint of the United States from Capitalism to Transnational during the 1960s by renouncing the restrictive laws in citizenship, hence, catalyzing the categorized birth of "Asian American" Moreover, he explains the ambivalent status of the Asian subject that has turned the Asian American into an "'abject' - as he [is] neither the total alien nor the full-fledged citizen" (Li, 1998, p. 6).

Postcolonial theory is polysemous since it foregrounds and problematizes the key relationship between the centre and periphery antagonism. In other words, postcolonial theory is an effort to create a counter critical discourse that contests hegemonic settings of modernity with other forms of enunciation to ironize and subvert unquestioned assumptions of binary oppositions. In Location of Culture (1994), the postcolonial critic, Homi Bhabha, states that postcolonial theory is an attempt to "interrupt", to read "contrapuntally" and "interrogatively" the tragic experiences of those dispossessed of voice and discriminated against to formulate critical revisions of "empowering strategies of emancipations" (Bhabha, 1994, p. 246). Thus, postcolonial criticism is not a monolithic theory with a fixed set of paradigms and it is essentially ambivalent, hybrid and disjunctive.

The globalized world represents "a gradual spectrum of mixed-up differences" (Greetz, 1988, p. 148). This underscores key concepts such as hybridity, diaspora and multiculturalism - entanglement rather than identity, togetherness-in-difference rather than separateness. The significance of diasporic identity lies in its force as a symbolic declaration of liberation from abject position of "ethnic minority" in an oppressive hegemony. Diaspora, with this rationale, provides a sense of transnational belonging and connection with dispersed others of similar historical origins: "diasporic identifications reach beyond ethnic status within the composite, liberal state" imparting a "sense of being a people, with historical roots and destinies outside the time/space of the host nation" (Clifford, 1997, p. 255). This highlights the premise that many Asian Americans do not see the local and the diasporic as contradictions. This explains the hyphenless spelling of the term "Asian American" that "affirms the indivisible integrity of the Asian American experience [and] to minimize any negative connotation associated with bilaterality" (Feng, 1995, p. 32).

Diaspora is a Greek word used to describe "the sowing of seeds and then applied to Greek colonization in the 
Mediterranean" (Cohen, 1997, pp. 117-20). Stuart Hall-the eminent cultural theorist and proponent of "Diaspora-as-diversity" (1994, p. 392) - regards diaspora as a coherent unit of geographically dispersed people bound by sentiment, culture and history. In Beyond the Bonders: American Literature and Post-colonial Theory (2003), Rajini Srikanth refers historically to diaspora which is a term that no longer applies only to the Jewish or African peoples: "Colonial dictates, labor migrations of the nineteenth and twentieth centuries, wars, and the globalization of "capital" have resulted in the wide dispersal of Asian such as the Indians, Chinese or Vietnamese to various regions of the globe-East Africa, the Caribbean, Latin America, England, Canada and the United States" (Srikanth, 2003, p. 93).

Global diasporas signify the transnational communities whose boundaries are porous and heterogeneous. In this sense, global diaspora is a triumph over the shackles of the national identity since it refers to a sense of belonging to more than one identity. Seen in this way, diasporas not only are placed in direct opposition to the nation-state, but are also implicitly designated as key socio-cultural formations capable of overcoming the constrictions of national boundaries. This foregrounds "the possibility of cultural hybridity that entertains difference without an assumed or imposed hierarchy" (Bhabha, 1994, p. 4). Hybridity, thus, refers to "the creation of new transcultural form" (Ashcroft et al., 1998, p. 20). Hybridity-as Robert Young postulates in Colonial Desire (1995) - is "a key term in that wherever it emerges it suggests the impossibility of essentialism" (Young, 1995, p. 27). Diasporic writings address problems that arise from the transnational space created neither by a fluid community that is neither at home nor outside and "such negotiation is neither assimilation nor collaboration" but an "interstitial space" that refuses "the binary representation of social antagonism" (Bhabha, 1994, p. 58).

Finally, postcolonial exploration of the effects of diaspora and immigration has contributed to map out the fabric of multicultural societies. Stuart Hall-in Critical Dialogues in Cultural Studies (1996) - states the significance of diaspora as a determinant factor in the configuration of identity, a cultural construct which in the context of multicultural environments he dissociates from purity relating it instead to heterogeneity: "Diaspora identities are those which are constantly producing and reproducing themselves anew, through transformation and differences" (Hall, 1996, p. 402).

\subsection{An Insider Asian American Perspective: Visually Illustrated}

What is remarkable about Belle Yang's Hannah is My Name (2004) and Guene Luen Yang's American Born Chinese (2006) is that both visual narratives are authentic representations of cultural hybridity of Asian identities: "an insider perspective is more likely to give an authentic view of what members of the cultural group believe to be true about themselves" (emphasis mine, Yukota, 1993, p. 158). Belle Yang's picture book is based on her experience immigration to the United States and Gene Yang's graphic novel is an embodiment of his experience as Asian American with a hybrid identity and also from his experiences as a high school teacher.

Pictorialization is a genre under debate that foregrounds the importance of visual literacy in the 21th century. The term literacy is itself under erasure since children today experience a constant stream of ideas and information online, in print and through electronic games and mass media. Pictorialization-manifested in films, picture book and graphic novels - takes the viewer away from current world to "a level of understanding deeper and wider than the limited lives may be to a world uglier or more beautiful, more humorous or more somber, simpler or more complex. And like the best of any art form, it forces us to confront the depths of our secret selves" (Lukens, 1990, p. 212). Pictorialization kindles imagination and represents a unique visual literacy within semiotic systems especially in multi-modal texts that generate interactive and fluid spaces between words and images that stimulate the child viewer's visual imagination to picture things which in some visuals are not there - namely - to disrupt the boundaries traditionally erected between art and everyday experience. With this rationale, the current study explores the following semiotic systems to pinpoint the authors' inside perspective of their Asian American identities:

- Linguistic: the vocabulary, generic structure and grammar of written language

- Visual: color, vectors and viewpoint of still and moving images

- Gestural: the movement, speed and stillness of facial expression and body language

- Spatial: the proximity, direction, position of layout and organization of objects in space

Pictorialization displays both conventional and iconic signs. The function of the conventional sign is to narrate and the function of the iconic signs is to represent. Together, conventional and iconic signs create a unified or total synergy that generates meaning in illustrated stories (Nikolajeva \& Scott, 2001). The logic of the image relies on image syntax to provide clues to interpret power relations. Pictorialization seeks the strong engagement 
to both images and words because the relation between the two can reinforce, alter or even undermine the apparent meaning of visual narratives. In other words, the denotative context of the narrative text is interpreted by the connotation of the visual text, thereby, an illustration is polysemous and the meaning-making is indefinite. What bends Hannah is My Name (2004) and American Born Chinese (2006) is that they are essentially explorations into visuals that tell stories and produce an aesthetic response. Visual images carry "their own peculiar kinds of visual-resistance, recalcitrance, argument, particularity, strangeness or pleasure" (Ross, 2007, p. 12). Finally, pictorialization is an embodiment of hybrid literature that tackles the interplay of word and image and the pivotal question: how do these images function as part of the text? This interplay is central to developing new ways of understanding how images work. This interplay creates a "third space" that is neither purely verbal, nor purely visual, a point examined by the visual scholar W. J. T. Mitchell in What Do Pictures Want? (2005): "The space between words and images is a kind of void into which (and from which) ideas, passions, narratives, representations emerge. It is the "third space", the in-between where contingency rules" (emphasis mine, Mitchell, 2005, p. 47).

\subsection{Hannah is My Name (2004): An Americanizing Journey towards Heterogeneity}

Belle Yang's Hannah is My Name (2004) is a picture book using gouache illustrations that reflect her own personal immigration experience to the USA in the 1960s and reflects the trend of immigrants at that time to form an identity based on assimilation. As an immigrant from Taiwan to San Francisco, her picture book reflects the aspirations of all immigrants to achieve the "American Dream" and to gain the green card status. The obstacles faced by the child protagonist Hannah presents a more romanticized reflection of the obstacles faced by immigrants. The struggle in this picture book is the fear of deportation while the family waits for the arrival of their green cards. This lack of documentation positions the immigrant family as illegitimate and as the "Other" in the USA.

Hannah's narrative of her journey to San Francisco undergoes three stages: uncertainty of identity, illegitimacy as an immigrant, and legitimization through assimilation. The analysis focuses on the spatial/symbolic relationship of objects and visual frames to demonstrate the identities and positions of immigrants during the 1960s as they begin the journey towards assimilation. In the initial two-page spread of the picture book, the uncertainty of identity for the immigrant is seen primarily with the loss of mother country and culture:

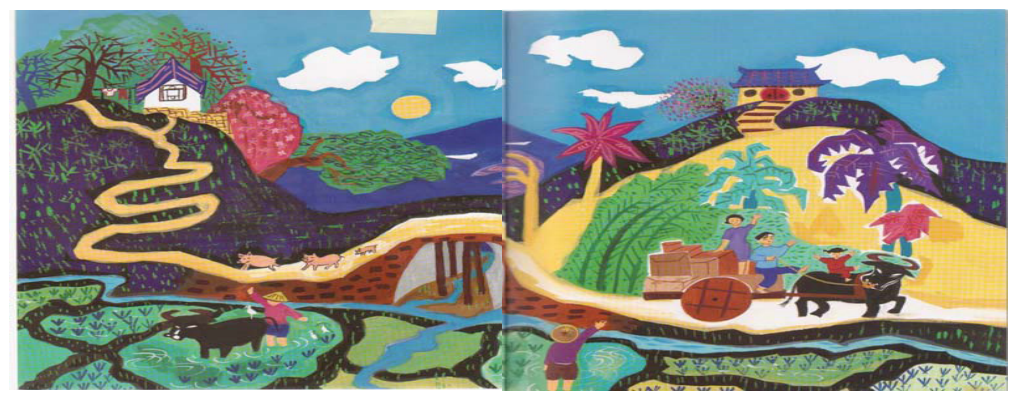

Figure 1. Hannah and her family leaving Taiwan

The "old country" is depicted as a primitive society with an ox cart for transportation and outdated farming clothing. The family is viewed as leaving a village depicting a romanticized view of Taiwan as a primarily agricultural country with rice paddies and farm animals. This two-page spread uses dark colors of blue, purple, green and yellow to reflect the seriousness of the journey. The faces of the villagers are featureless while Hannah and her family have minimal strokes to depict their eyes, nose and mouth. The neighboring farmers are in rice paddy hats waving good-bye, giving the sense that the Lin family will never return. The clouds in the sky are large and loom over the sun, creating a sense of doom and pain in the picture. The picture is from a far angle and Hannah and her father are positioned seated but with one leg up giving the impression that they are ready to run from the old country. Hannah's mother is standing like a queen and waving to her adoring subjects as the Lin family is lucky to leave. The lack of details in the members of the Lin family and the neighbors' facial expressions give the impression that the life in Taiwan is inferior to the life in the United States. The portrayal of Taiwan as a primitive agrarian society provides a juxtaposition of life in San Francisco as an urban and modern city legitimizing the need for the Lin family to immigrate. The romanticized portrayal of Taiwan as a rural 
country positions the USA as a more desirable and dominant society and foreshadows the Lin family's need to assimilate to the USA urban lifestyle.

The Taiwanese protagonist begins her narrative with "Hannah is my name in this new country. It doesn't sound at all like my Chinese name, Na-Li, which means beautiful" (Yang, 2004, p. 2). The introductory words underscore the strong bond between names and identities as she herself says it is "strange to become Hannah all of a sudden" (Yang, 2004, p. 2). Her security with her name is altered, as she reverts to her nickname, Tadpole, because it is more comfortable to her and the tadpole symbolizes Hannah being in the early stages of growth in a life cycle. In this case, her life cycle is the cycle of turning from being Taiwanese to being Asian-American. In the next image, Hannah is lying on the beach playing in the waters of Taiwan with frogs and tadpoles surrounding her:

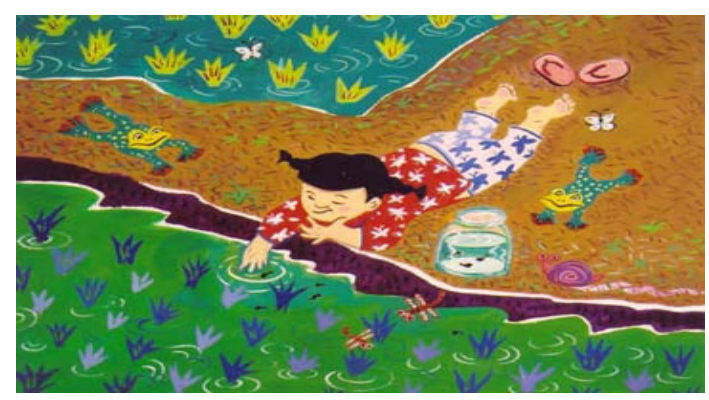

Figure 2. The accompanying text reads: "I used to catch tadpoles in the rice paddy and put them in a jar to watch them grow into frogs. That's when we lived in Taiwan, an island off the coast of China."

She has a slight smirk on her face, but looks content, surrounded by the symbols of her nickname. The smirk on her face and her relaxed body portray the binary opposition of her identity crisis as she is content yet unsettled after being uprooted to a new country. Moreover, this image symbolizes the transitional stage of leaving Taiwan in order to settle in San Francisco. The idealization of life in America is seen when Hannah says "When we are Americans, Baba says, we will be free to say what we think. An American girl is free to be anything she chooses, says Mama" (Yang, 2004, p. 2). For the Lin family, America represents the land of wealth and prosperity because Hannah and her family want to be "free" and to "become Americans more than anything in the world" (Yang, 2004, p. 2). For the Lin family, assimilation into being "Americans" is their goal for immigration. The immigration to America causes distress for Hannah who holds onto her nickname "Tadpole" as the tadpole represents her connection to herself in Taiwan, but also herself in San Francisco, as she is still called "Tadpole" at home. Thus, this nickname helps her bridge her sense of identity as Na-Li and as Hannah. The tadpole is also a significant symbol as a tadpole is the preliminary stages of the frog life cycle, until it grows to become a frog. The tadpole is legless and vulnerable to the environment similar to how Hannah as a new immigrant is left vulnerable due to her lack of legitimacy without a visa.

The Lin family - in their journey to American citizenship - is left labeled as illegal bodies. When finding a home or employment, Hannah and her parents have limited choices. Their first home at 636 Bush Street does not allow children. However, Jewel, the building manager, decides that Hannah can stay as long as she is quiet. Hannah is forced to believe that she must be as quiet and invisible as possible to not disturb others as she is technically not allowed to live in the building. Belle Yang depicts how Hannah with an unhappy and worried expression tries to hide behind her mother as much as possible to show Jewel that she can be quiet and silent: 


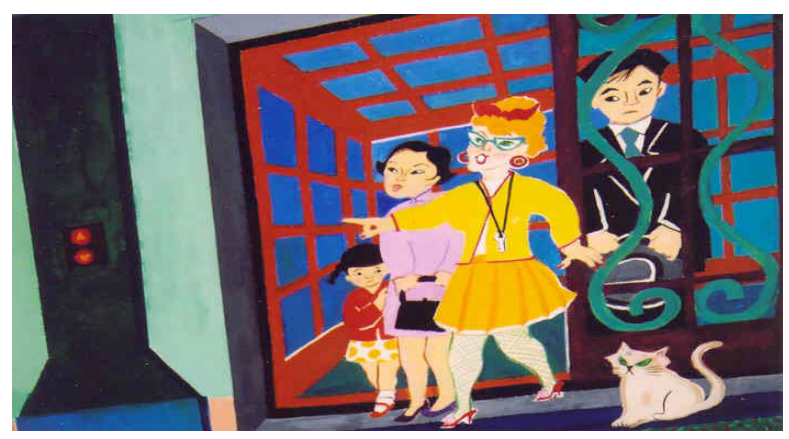

Figure 3. Elevator

Her toes are pointed forward tip-toeing to minimize her noise production. In their first home in the USA, Hannah is forced to pretend that she does not exist and already as a new immigrant is told she is not welcomed. Hannah's father is depicted behind the elevator doors like the bars of a jail cell which Hannah describes as being like "a lion's cage". Already, the Lin family is trapped and limited in their choices as Jewel, the manager, is the one holding the power and key to their new home. Jewel's glasses are cat-shaped, and her eyes are mirrored in her cat's expression with an almost wicked expression of power. Even the pet of the manager holds a more prominent position as Hannah's father is located behind the cat within the picture. The use of geometrical shapes creates a 2-D effect of the Lin family almost in a cell that appears to overpower them.

The second step in their immigration process is to file immigration papers. Powerless without language, the family relies on Mr. Choo in Chinatown for his English skills. Hannah and her mother visit Mr. Choo who is depicted as an imposing unsmiling man who sits at his large brown desk with a lineup of other people waiting for his assistance. His message provides little comfort as Hannah's mother and father are not allowed to work without green cards. Hannah has to comfort her mother who sits despondently on the couch after being fired from her job sewing buttons at the factory. There is a lampshade on the left that provides some light in the room, but the window shows that it is dark outside with a half moon. The house key is left outside of her mother's purse, as if even ownership of their home eludes them without the green cards as America is not their home until they are citizens. The greatest symbol of their fear as illegitimate bodies in America is the threat of the immigration inspector. The inspector is depicted in a dark trench coat and hat that covers half of his face. Aside from the side profile of the nose, the inspector is portrayed as a dangerous and frightening figure who could be anyone, even the bell hop that Hannah's dad relies on to elude deportation. In the background, Hannah and her father are shown as small figures in the same space as the dangling spider that could be squashed or ignored by humans.

Instead of using bright pastel colors of previous pages, Belle Yang uses dark blue and green tones to highlights the Lin family's sense of danger for her and her family. The fear of deportation is especially poignant when Hannah's friend Janie is deported after her father was caught working illegally. When Janie leaves, she gives Hannah her pink rabbit's foot and wishes of luck while Hannah gives Janie her name bracelet to remember her by. At a young age, Hannah must deal with the loss of her close friend as Janie's absence leaves "a big hole inside [her] chest" (Yang, 2004, p. 15). Their parting scene shows how the two immigrant children are separated on the playground by a cement barrier while other children on the other side are playing happily on a swing set and slide with the Bay Bridge and Coit Tower behind. The division of the picture emphasizes how the legitimate children are able to enjoy the sights and landmarks of San Francisco while Hannah and Janie are left separated as immigrant children.

When the green cards arrive, Hannah sees her English name "Hannah Lin on the cards". She states "It has my name printed importantly on it. Not Tadpole, but Hannah Lin" (Yang, 2004, p. 22). For Hannah, she has assimilated her identity through being officially labeled "Hannah Lin". She no longer refers to herself by her Chinese name, Na-Li, but feels that "Hannah doesn't sound like a stranger's name anymore. It's my name. Hannah is my name. And America is our home" (Yang, 2004, p. 22). By having the green cards, Hannah believes that she can fully assimilate into her new identity as "Hannah" and that she can finally be safe in America as she does not have to "stay quiet and make ourselves small" (Yang, 2004, p. 22): 


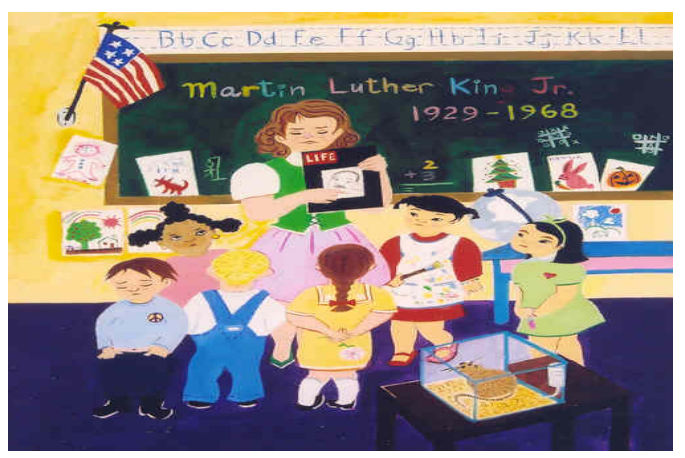

Figure 4. Hannah's school

The text says: His name was Martin Luther King. "He wanted all people to be treated fairly," she said, "whatever the color of their skin."

This visual depicts the American flag in association with Martin Luther King to signify the belief that America is the land of freedom and liberty. The idea of diversity is enhanced and visually illustrated in the different skin complexion of the students as well as the colors of their hairs: the African with the curly dark hair, the blond with the yellow hair and the Asian with the straight black hair.

In the last visual, Hannah and her family finally have full smiles on their faces and the background is in bright yellow tones which symbolize happiness and comfort, rather than the dark blue and green tones of the previous illustrations:

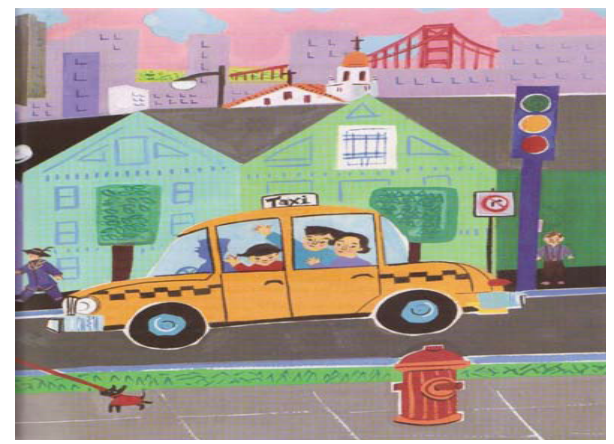

Figure 5. Celebration

For Hannah, her sense of identity is confirmed when she is finally able to embrace her American name, Hannah, as her own. The last two pages - after receiving the green cards - show the Lin family waving from a taxi cab with fully detailed facial expressions and rosy cheeks. Yang uses bright pastel colors of green, purple, pink and yellow, with a large sun which beams behind the buildings to signify the brightness of their new life and also their legitimacy as they no longer have to hide in the shadows. San Francisco is depicted as a modern urban city with houses, cars and stop lights. Instead of having farm animals, there are domesticated animals as pampered pets. The Bay Bridge and Coit Tower are in the background and the bystanders in the background have full facial features as well. The Lin family is also viewed with a closer shot and this time the father is not driving the ox cart, but he waves his hand like a celebrity. Their transformation into American citizens is represented through a taxi ride in the streets of San Francisco symbolizing the attainment of the "American Dream". This transformation is visually illustrated in the front cover of the picture book which depicts the physical freedom of movement of Hannah and her mother: 


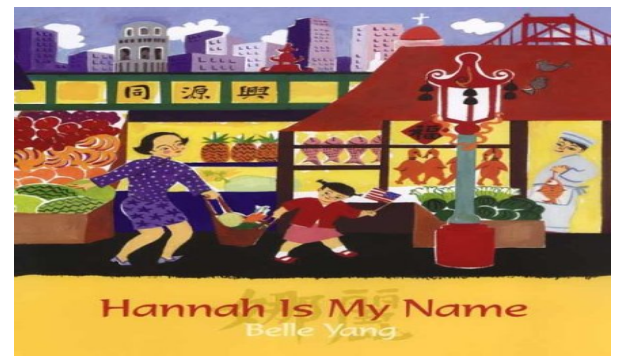

Figure 6. The front cover

The United States has long been a place of refuge and opportunity for immigrants from all countries. This simple picture book celebrates the shared history of diverse nationalities by telling the story of a little girl who is waiting for her green card and who meanwhile must adjust to a new way of life and a new language.

\subsection{American Born Chinese (2006): A Postcolonial Graphic Novel}

American Born Chinese (2006) - a multi-graphic novel — is a 2006 National Book Award Honor Book for Young People's Literature, the 2007 Winner of the Michael L. Printz Award honoring literary excellence in Young Adult Literature, the Winner of the 2007 Eisner Award of Best Graphic Album (American Library Association, 2010). It recounts the fictional story of Jin Wang, a second-generation American-born Chinese boy living in San Francisco. Other two connected narratives interwoven throughout the graphic novel: one is the mythological tale of the Monkey King and the other revolves around the antics of Chin-Kee, a representation of negative Chinese stereotypes:

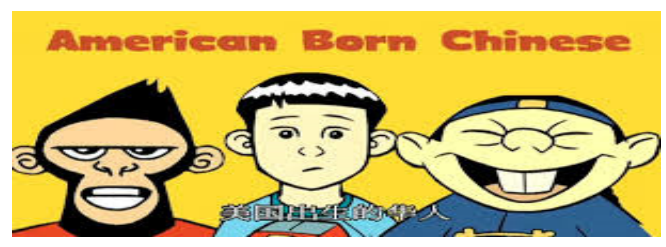

Figure 7. Front cover

To grapple with questions of racial consciousness, Gene Luen Yang layers the separate narratives of Jin Wang, Chin-Kee, and the Chinese mythological character of Monkey King to address the inner workings of an outsider identity and the struggle to fit in. The three separate narratives come together towards the end of this graphic novel where it is revealed that Jin accepts a chance to magically turn himself white and subsequently calls himself Danny; Chin-Kee is actually the Monkey King in disguise who visits Jin/Danny to serve as his conscience. In the finale, the Monkey King reveals himself and Danny reverts to Jin and Jin reconciles himself with his Chinese American identity. In an interview conducted by S. Woan (2007), G. L. Yang examines assimilation: "I'm still trying to figure out what it means to be Asian American. There's definitely a temptation to become fully assimilated, fully a part of America, but as Asian American, we have to constantly struggle against that" (Woan, 2007, p. 78). This pinpoints the complex balancing act between acculturation and assimilation that second-generation immigrants may experience: living in two often contradictory cultural worlds.

In American Born Chinese (2006), preceding each chapter, there is a page with a small pictorial depiction of character that creates curiosity about this character and the white space around the image or the gutter creates absence which lets the reader to focus on the depicted character whose particular facial expression provides symbolic hints as manifested in the astonished face of the Monkey King, the gloomy expression of Jin Wang and the bizarre appearance of Chin-Kee. Furthermore, each "chapter" of G. L. Yang's graphic novel is indicated by the use of the Chinese red seal. This provides the visual cues to indicate the interweaving of the three separate plotlines of the Monkey King's Journey to the West, Jin Wang's experiences of growing up in a predominantly American neighborhood, and the Chinese sitcom of Chin-Kee. The use of the Chinese seal gives G. L. Yang's artwork a sense of legitimacy as the Chinese seal is a sign of ownership and it highlights the hybrid nature of G. L. Yang's medium - the graphic novel. G. L. Yang uses the Western graphic novel format, but it includes the Chinese seal to identify each section. 
G. L. Yang's American-Born Chinese discusses the immigrant's minority experience of navigating between internal and external pressures interweaving many Asian and Western symbols to create a hybrid story in a hybrid format. The change in color between the three plot lines demonstrates a reflection of each character's journey to acceptance. The Monkey King, a deity in Chinese culture, is depicted with tones of red and orange while Jin is portrayed with blue. The color red in Asian cultures is usually a symbol of wealth and prosperity while red and orange are considered "warm" colors in Western cultures. The red color can be reflective of the Monkey King's status as a god. Jin, on the other hand, is associated with blue which is a "cold" color in the Western world. The transition between warm and cold colors can symbolize the change in their identity quest as they move from denial to acceptance. The use of blue in Jin/Danny's storyline - a "cold" color - can demonstrate how isolated he is from his ethnic identity whereas the ending of red and gold symbolizes the warmth of embracing his ethnic identity.

To underscore racial self-hatred aesthetically, a series of three panels depict a new comer to Jin's classroom, Wei-Chen, who is visually seen small and powerless at the center. The teacher mispronounces his name and makes mistakes regarding the student's background. These blunders signify the teacher's lack of linguistic and cultural knowledge about students who do not represent the mainstream. In the top panel, there is a map of the United States of America drawn without designation of the States' lines and in a colorless hue. This signifies that the school curriculum portrays the culture of the United States as monolithic. In the final panel, Jin is positioned as align with his White classmates gawking at Wei-Chen who is a threat to Jin's attempt to fit in.

The graphic novel can be regarded a subversive tool and a counter-hegemonic force that can empower the minority groups to rise against the dominant White race. By attaching humor to Chin-Kee's character and mannerisms, G. L. Yang juggles with the common misconceptions of Chinese Americans that proliferate in both historical and contemporary discourses in the United States. Towards the end of the graphic novel, Chin-Kee uses techniques such as "mooshu fist" and "kung pao attack" (American Born Chinese, 208). This pairing of food names and fighting seems to be symbolic of a deeper fear regarding Chinese food invading the Unites States of America. Regarding the textual complexity of the graphic novel, Lisa Echert Schade refers-in "Protecting Pedagogical Choice: Theory, Graphic Novels, and Textual Complexity" (2013) - to the visual moment of illumination in which "Jin begins to clearly develop a sense of authentic identity and embraces his cultural ethnicity more vividly" (Schade, 2013, p. 43):

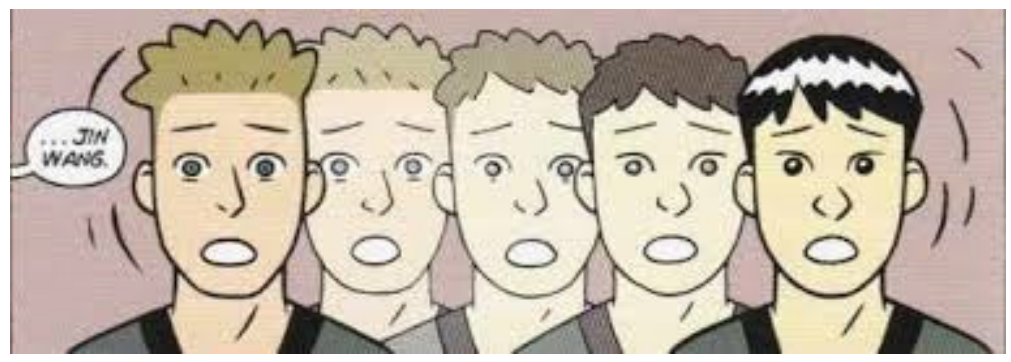

Figure 8. "The moment within moment" frame

Identity is an inescapable discourse within the realm of trans-nationalization. Culture, history and ethnicity are intertwined aspects which influence identity formation: "identities are produced, consumed and regulated within culture - creating meanings through symbolic systems of representation about identity positions which we might adopt" (Woodward, 1997, p. 2). The depiction of the unstable identity construct of a second-generation immigrant represents the core of the identity discourse: identity becomes a discourse when it is in crisis, namely, when something assumed to be fixed, coherent and stable is displaced by the experience of doubt and uncertainty. Finally, the prominent visual theorist Gerard Genette refers to the vital functions of "paratext" which performs "a material function (presenting the primary text as a tangible book package) and a rhetorical/communicative function" (Genette, 1997, p. 1). With this rationale, the "paratext" of American born Chinese as a multi-graphic novel is very useful to explore design elements-like typography, book cover illustration and image syntax as well as to affect the interpretation of a postcolonial text.

\subsection{American Born Chinese (2006): A Grotesque Journey towards Hybridity}

In G. L. Yang's American Born Chinese, the symbols and racial stereotypes interlaced in the graphic novel to 
exemplify Jin's visual journey towards a hybrid identity and it begins with the denial of his ethnic self and the resolution of Jin's journey is triggered by his cousin's Chin-Kee's arrival. Chin-Kee embodies many immigrant Chinese stereotypes that are mocked by G. L. Yang and help Jin to come to terms with who he is. G. L. Yang uses these stereotypes for comedic effect and through hyperbolic representations; he also highlights the absurdity of such stereotypes. The conclusion of Jin's journey is his acceptance of his hybrid identity.

G. L. Yang interweaves the Monkey King character who is himself a hybrid: a monkey and a deity. The character of the Monkey King is a respected East Asian mythical creature from Journey to the West, one of the Four Great Classical Novels of Chinese Literature. G. L. Yang presents the Monkey King's quest to find his own identity among the gods as he is mocked for being essentially a monkey. To eradicate his identity as a monkey, the Monkey King tries to transform himself into the "Great Sage, Equal of Heaven" unleashing a reign of terror on the other deities and gods. When Tze-Yo-Tzuh states that the Monkey King has been created to be a monkey and cannot change his identity, the Monkey King tries to remove the monkey part of his identity and is thus imprisoned in a rock cave. The Monkey King's quest to change his identity is ignited when the gods imply that the Monkey King's lack of shoes diminishes his status as a deity, leaving the Monkey King humiliated and feeling illegitimate. To change this, the Monkey King decrees in his monkey kingdom that monkeys must wear shoes, a human-like characteristic, which render them incapable of climbing trees and in essence, from being monkeys. This attempt to physically change one's physical identity is a theme carried on by the human protagonist - Jin Wang - who tries to eradicate his Chinese identity and become Caucasian. The Monkey King's experience is used to link the Chinese mythology with the American-Chinese hybrid experience of Jin.

Jin Wang's storyline begins with an old Chinese parable describing how a mother has located her son in a refined district to become a respectable scholar. This parable is based on the belief that the environment decides who you will become. In the parable, when the family lives near a marketplace, the son becomes a haggler, when they move near a cemetery, the son burns incense, and when they move near an university, the son becomes a respectable scholar. This parable precedes Jin's family's move to suburbia and out of San Francisco's Chinatown. This family's relocation causes Jin to follow the path of the parable, and desire to become like everyone else in his environment-Caucasian. Jin's reinvention mirrors the Monkey King's experience as Jin begins to imagine himself with blond curly hair. The blond hair color is a decidedly advantageous physical characteristic and is one of the biggest indicators of a desirable Western characteristic which is alien to his natural genetics. Jin believes that his Chinese ethnic physical traits prevent him from chasing the girl of his dreams, Amelia. In his belief that he is inadequate compared to Greg, he perms his hair which causes his friends Suzy and Wei-Chen to question his decision. In his attempts to change himself, Jin ironically causes himself to be labeled "a geek" (Yang, 2006, p. 184). When Jin finally courts the girl of his dreams, Amelia, he is ecstatic. Unfortunately, his own insecurity causes him to agree to not date her after a request from Greg, the blond curly haired popular boy that Jin idolizes. Greg's claims that high school reputations depend on who you associate with exacerbates Jin's insecurities with his own identity. Jin replays the scene in his mind wishing that he had the voice and courage to say "No" when asked to not date Amelia. The reason is to "hang out with the right people" as well as the need to watch for "appearances" (Yang, 2006, p. 179) causes Jin to feel obligated to Greg and promise to end a possible burgeoning inter-racial relationship. As a second-generation offspring, Jin is left feeling voiceless and powerless. This causes him to loathe himself even more and his increasing insecurities make him act awkwardly with others which causes Greg to label him as "kind of a geek" and to ask "What's with the hair?" (Yang, 2006, p. 184), further alienating him from the community he desires to join. The Monkey King and Jin both experience turning points in their lives where they are unable to accept their identity. When he refuses to accept Tze-Yo-Tzuh's wisdom, he is left to fall under a pile of rocks. In his human-like form, the Monkey King is left helpless under a "trapping" seal to prevent him from using his martial skills. The closing frame chapter on the Monkey King's story shows his imprisonment state and the "trapping" seal reinforces the image of self-imprisonment within the rocks. The pile of rocks dominates the frame and positions the Monkey King as a small figure within nature.

The cost of Jin's self-denial is the loss of his two friends, the Japanese female student Suzy and Wei-Chen. When Wei-Chen confronts Jin by saying: "We're brothers, Jin" We're blood" (Yang, 2006, p. 190), Jin attacks him because he is lower than him since Wei-Chen is a newer immigrant and thus even more illegitimate calling him an "F.O.B" (Yang, 2006, p. 191). By labeling Wei-Chen as an F.O.B. or "Fresh off the Boat" immigrant, Jin is reiterating the racist attitude he has faced with Greg. During Wei-Chen's confrontation with Jin, the two are angled to face each other. The first frame focuses on the eyes of each boy with the shape of the eyes being exactly alike, highlighting their physical similarities, despite Jin's attempts to categorize Wei-Chen as a F.O.B. As the boys communicate, the images position the reader in each following frame from either Wei-Chen's or Jin's perspective. When viewing the scene from Wei-Chen's perspective, Jin is angled to be lower than Wei-Chen 
as a visible sign of Jin's betrayal, while from Jin's perspective, Wei-Chen is perceived at a lower angle due to Jin's belief that a F.O.B. is of lower social status to a first-generation immigrant child. The Monkey King's and Jin's actions cause both of them to be alienated from their true selves and their own self-denial causes them to be trapped in foreign bodies.

When Monk Lai-Tsao meets the Monkey King, he tells him that "returning to your true form is not an exercise of kung-fu" (Yang, 2006, p. 145) advising him to return to his true form and he shall be freed since he has imprisoned himself in his altered human-like form as well. In the end, the Monkey King reverts to his true monkey animal form with the monk reminding him he does not need shoes. The closing frame of the Monkey King's story line delineates the footprints of the monk and the monkey in the sand as they journey to the West. This image reaffirms the ability of man and monkey to co-exist in their natural state side by side (Yang, 2006, p. 160) and also builds a connection to Mary Stevenson Zangare's Christian poem "Footprints in the Sand" which visualizes Jesus walking in the sand beside believers in the journeys of life. Thus, Yang connects Buddhist imagery and Christian imagery into one creating a hybrid frame. The Monkey King's decision to abandon the idea of wearing shoes also shows how he is more submissive to monk Lai-Tsao in his original monkey god form than in his human-like god form as the "Great Sage-Equal to Heaven".

G. L. Yang distorts the construction of the bodies of the Monkey King and Jin to show the internal journey of constructing their identity. The Monkey King changes from his animal form to a human-like form with monkey features while Jin transforms into the curly-haired blond Danny. The change in character portrayal when Chin-Kee reverts to his original self as the Monkey King and Danny changes to being Jin again demonstrates a change in the typical positioning of characters to the left being stable and safe, or in danger when on the right of a page. Rather, the Monkey King and Jin are back to positions of stability as their original selves. When Wei-Chen begins to trust Jin and his offer of friendship again, the close up shot of the bubble tea drinks highlights the symbol of their new bond and the recognition of their hybrid status as Chinese and American communicating in Mandarin and English.

\subsection{American Born Chinese (2006): A Visual Mockery of "Asian" Stereotypes}

The image of the Asian male is stereotypically personified as safe and asexual. In G. L. Yang's American Born Chinese, Chin-Kee, the caricature Asian Male, is depicted with round features, signifying a more accommodating and safe nature. In contrast, Danny, as Jin's Caucasian person, has a square and more masculine shape. Jin, in his original form, has softly rounded features, signifying his hybrid status, between the dominant Western Anglo male, and the passive Asian male. The timing of Chin-Kee's visit is noteworthy. He enters the text just as Danny is becoming close with his White Friend Melanie. Danny is always forced to switch schools because he can never feel comfortable being "Danny". Chin-Kee's visits serve to remind Danny that he is still connected to his Chinese heritage and that his attempts to escape it cause him to act irrationally as seen in his argument with his dream girl Melanie and his fight with Chin-Kee.

Jin/Danny's personality split is the outcome of his fabrication of an alter-ego to subjugate his ancestral heritage. He attempts to repress his Asian roots banishing it into the realm of the unconscious. However, the character of Chin-Kee is an embodiment of the "return of the repressed" (Freud, 2001, p. 952). Therefore, the personas of Danny/Jin and Chin-Kee reflect the inner struggle of the Asian American subject who strives to be identified with the dominant White race. Jin emblematizes what David Li addresses as the "Asian abject" (Li, 1998, p. 6), a part that he willfully struggles to discard. Jin, wei-Chen and Chin-Kee are a source of anxiety that threaten to dispossess the Anglo-Saxon America. This pinpoints the historical construction of Asian heritage as "an object of national prohibition" (Li, 1998, p. 7).

The stereotypical old 1940s Hollywood image of the Chinese male is personified in G. L. Yang's comedic character Chin-Kee, the "cousin" of Jin/Danny. Chin-Kee arrives to visit Danny wearing the traditional Mao-era attire, with Manchurian style of the ponytail for Chinese males, the cap, and the heavily accented "Chinglish", and the inability to pronounce the $/ \mathrm{r} /$ and $/ 1 /$ sounds of English: 


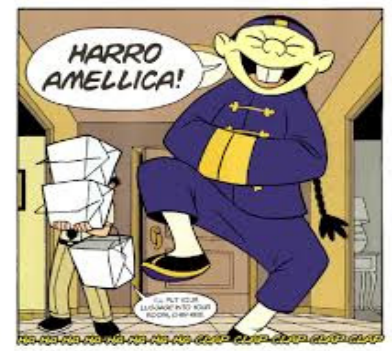

Figure 9. Chin-Kee's annual visits

Chin-Kee represents everything about the Chinese identity that Danny strives to forget, the spittle when talking, the buck teeth, the loud voice, and the Karaoke-style singing, all demonstrated at Danny's school leaving Danny mortified. G. L. Yang subtly explores the racist stereotypes that are advocated by dominant Western cultures through the hyperbolic representation of Chin-Kee.

Chin-Kee embarrasses his cousin by knowing the answer to every question posed in the classroom (Yang, 2006, pp. 111-113) and a White classmate is afraid that chin-Kee's spit will infect him with the SARS virus (Yang, 2006, p. 202). Moreover, Danny catches a couple of White students making slant eyes and laughing at Chin-Kee's antics (Yang, 2006, p. 121). Dramatically, Chin-Kee functions as an oriental comic relief in an absurd style. Chin-Kee sings Ricky Martin's pop song "She Bangs" to the shock of Danny's classmates and teachers. The song mirrors the performance by Asian American, William Hung, who in 2004 sang the same song for the hit show "American Idols" (Fu, 2007, p. 275):

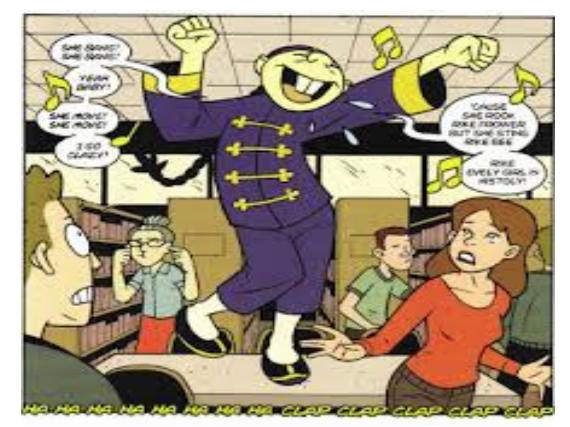

Figure 10. Cousin Chin-Kee's antics at Danny's school

The Chin-Kee's farcical narrative is framed like a sitcom as visually manifested in the running laugh track at the bottom of the frame. Chin-Kee is revealed to be the Monkey King in disguise, who is there to help Danny accept his hybrid identity as a Chinese-American male.

The denouement of the novel takes place when Ckin-Kee's antics and ludicrous jokes enrage Danny. The fight between the two boys takes the form of a kung-fu movie in which Chin-Kee exhibits his superior skills till Danny lands a lucky punch that knocks Chin-Kee's buck-tooth and his head is cut off. The Monkey King reveals his disguise as Chin-Kee: "Now that I've revealed my true form, perhaps it is time to reveals yours" (Yang, 2006, p. 213): 


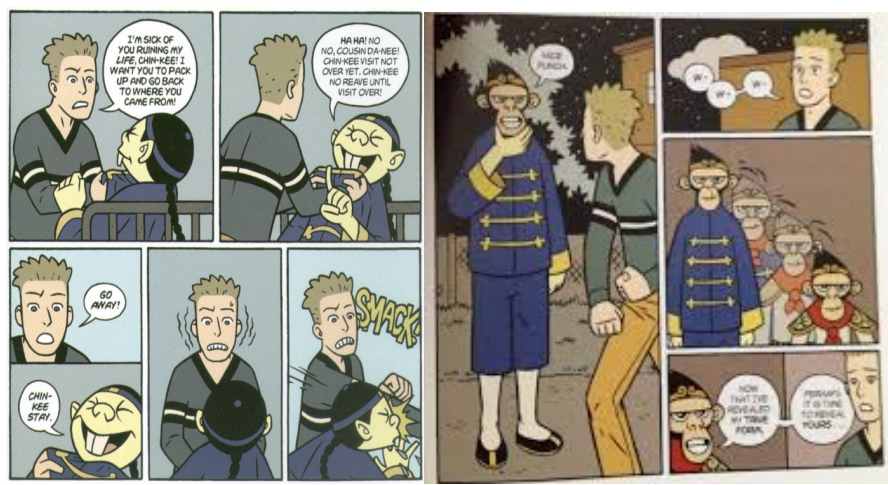

Figure 11. The climax: the moment of revelation

The Mythological character says: "You misunderstood my intentions, Jin. I did not come to punish you. I came to serve as your conscience - as a signpost to your soul" (Yang, 2006, p. 221) and Danny is transformed into Jin. The finale depicts the two of them in a video together signifying Jin's reconciliation with his own identity.

\section{Recapitulations}

The visuals - in both narratives - refer to sign systems to underlie the significant use of fonts, symbols, objects and other elements of discourse that may be perceived and interpreted in various ways since the logic of the image depends on the image syntax. On comparing G. L. Yang's graphic novel to Belle Yang's picture book, the former author/illustrator's medium is more sophisticated with a unique poetics in which word, image and typography interact meaningfully and which is in tune with the complexity of perplexed life of an immigrant's identity crisis. In Understanding Comics: The Invisible Art (1993), the renowned theorist Scott McCloud states that graphic novel "was trivialized in the past, but it has become a form of popular culture" (McCloud, 1993, p. 201) capable of giving a picture of complex issues. Within this rationale, American Born Chinese is a multimodal visual text since it is non-linear narrative and the reading rhythm changes manifesting its own codes of visual logic and image syntax standing in contrast to the hierarchy, centrality and linearity of Belle Yang's Hannah is My Name. The linear movement of Hannah is My Name is a reflection of a steady rhythm to create an expectation of orderly procession of events and action and its visuals successfully can be evaluated for plot, character, setting, style and theme.

\section{Conclusion}

The present study is a critique of Asian American Diaspora. Asian American literature poses a question of profound importance to the Asians in the United States of America: "Who are you?" The question refers to the state of being "local", "foreign" and "Other". This highlights the web of interlocking and interrelated themes of nostalgia, belongingness, alienation and identity turmoil. The west has misrepresented the "Orient" as mystic place of exoticism, moral laxity, sexual degeneracy and so forth. The renowned postcolonial critic Edward Said defines "Orientalism" as "Western style for dominating [and] restructuring authority over the Orient" (Said, 1978, p. 3). The dramatic postcolonial state of "ambivalence" is defined by R. Young as "a simultaneous attraction toward and repulsion from an object, person or action" (1995, p. 161). To copy or not to copy the White dominant subject is the core of postcolonial concepts of "mimicry". H. Bhabha deploys the concept of "mimicry" to describe the "ambivalent" center/periphery relationship. Mimicry is both "resemblance and menace" (Bhabha, 1994, p. 86) as well as "equivocal" (Bhabha, 1994, p. 175). Danny/Jin's cosmetic transformation cannot undo his White classmates' perception of him. As Danny comments "no one thinks of me as Danny anymore. I'm Chin-Kee's Cousin" (Yang, 2006, p. 127), he is, paradoxically, reunited with his cousin at the finale of the story. The anxiety connected to this "double consciousness" is conveyed through a mixed-race character whose biological blend of races comes to stand for the cultural in-betweenness of the subject. What is worth remarking that the situation of the Chinese in the United States is not properly "colonial", but it is an inescapable fact that during the $19^{\text {th }}$ century, Chinese subjects have suffered the effects of the imperialistic policies of the United States of America, thereby, the Chinese/American postcolonial status can be interpreted as one of the internal colonialism. Danny and Wei-Chen are ridiculed for being "dog eaters" (Yang, 2006, p. 32), a traditional racist taunt. Whereas they are denigrated by racist White students, Hannah is fully assimilated with other ethnic identities at her school reflecting an idealistic vision of Americanization and heterogeneity. In contrast to Jin/Danny's personality split, Hannah represents the utopian concept of melting pot that seeks a new unity out of different cultures as well as the notion of the flexible citizen whose aspirations are 
simple, clear and direct, that is, to be fully assimilated to American culture and social habits. She cherishes the "Third Space" where identity in all its ambiguities is constructed and reconstructed peacefully. Hannah's immigration to America - within Bhabha's rhertoric of hybridity - is "how newness enters the world" (Bhabha, 1994, p. 227) and it is bound up with a "process of translating and transvaluing cultural differences" (Bhabha, 1994, p. 252). Finally, searching for identity is the driving force for both Hannah and Jin/Danny to find out who they are and which culture defines them and their journeys signify their attempts to fit in.

\section{References}

American Library Association. (2010). Wikipedia, The Free Encyclopedia. Retrieved from https://en.wikipedia.org/w/index.php?title=American_Born_Chinese\&oldid=696866666

Ashcroft, B. et al. (1998). Key Concepts in Postcolonial Studies. London \& New York: Routledge.

Bhabha, H. (1994). The Location of Culture. London \& New York: Routledge.

Chae, Y. (2008). Politicizing Asian American Literature: Towards a Critical Multiculturalism. New York: Routledge.

Chan, J. et al. (1974). Aiiieeeee! An Anthology of Asian American Writers. Washington: Howard University Press.

Childs, P., \& Patrick, W. (1997). An Introduction to Postcolonial Theory. London and New York: Hemel Hempstead. Prince Hall.

Clifford, J. (1997). Routes: Travel and Translation in the late Twentieth Century. Cambridge, MA: Harvard University Press.

Cohen, R. (1997). Global History and Migrations. In W. Gungwa (Ed.). Boulder, Colo: Westview Press.

Elaine, K. (1982). Asian American Literature: An Introduction to Writings and Their Social Context. Philadelphia: Temple University Press.

Feng, Peter (1995). In Search of Asian American Cinema: Cineast. America's Leading Magazine on the Art and Politics of the Cinema, 21(2-3), 32-36.

Freud, S. (2001). The Norton Anthology of Theory and Criticism. New York: Norton.

$\mathrm{Fu}$, B. (2007). Review of American Born Chinese. MELUS, 32(3), 274-276. http://dx.doi.org/10.1093/melus/32.3.274

Genette, G. (1997). Paratexts: Thresholds of Interpretation. Cambridge: Cambridge University Press. $\mathrm{http}: / / \mathrm{dx}$.doi.org/10.1017/CBO9780511549373

Greetz, C. (1988). Works and Lives: The Anthropologist as Author. Cambridge: Polity Press.

Hall, S. (1994). Colonial Discourse and Postcolonial Theory: A Reader. In P. Williams \& L. Chrisman (Eds.). New York: Columbia University Press.

Hall, S. (1996). Critical Dialogues in Cultural Studies. In M. David \& C. Kuan-Hsing (Eds.). London \& New York: Routledge.

Lee, R. G. (1999). Orientals: Asian Americans in Popular Culture. Philadelphia: Temple University Press.

Lewis, D. (2001). Picturing Text: The Contemporary Children's Picture Book. London: Routledge.

Li, D. (1998). Imagining the Nation: Asian American Literature and Cultural Consent. California: Stanford University Press.

Lukens, R. C. (1990). A Critical Handbook of Children's Literature. Oxford, Ohio: Miami University Press.

McCloud, S. (1993). Understanding Comics: The Invisible Art. New York: Kitchen Sink Press.

Mitchell, W. (2005). What do Pictures Want? The Lives and Loves of Images. Chicago: University of Chicago Press.

Nikolajeva, M., \& Scott, C. (2001). How Pictures Work? New York: Garland.

Ross, G. (2007). Visual Methodologies: An Introduction to the Interpretation of Visual Material. London: SAGE Publications.

Said, E. (1978). Orientalism. London: Penguin.

Schade, E. L. (2013). Protecting Pedagogical Choice: Theory, Grsphic Novels and Textual Complexity. 
Language Arts Journal of Michigan, 29(1), 40-43.

Srikanth, R. (2003). Beyond the Borders: American Literature and Post-Colonial Theory. London: Pluto Press Woan, S. (2007). Interview with Gene Luen Yang. Kartika Review, 1, 77-88.

Wonham, H. (2004). Ethnic Caricature and American Literary Realism. New York: Oxford University Press. http://dx.doi.org/10.1093/acprof:oso/9780195161946.001.0001

Woodward, K. (1997). Introduction. Identity and Difference. London: SAGE Publications.

Yang, B. (2004). Hannah is my Name. Cambridge: Candlewick Press.

Yang, G. L. (2006). American Born Chinese. New York \& London: First Second.

Young, R. (1995). Colonial Desire: Hybridity in Theory, Culture and Race. London \& New York: Routledge.

Yukota, J. (1993). Issues in Selecting Multicultural Children's Literature. Language Arts, 70, 156-167.

\section{Copyrights}

Copyright for this article is retained by the author(s), with first publication rights granted to the journal.

This is an open-access article distributed under the terms and conditions of the Creative Commons Attribution license (http://creativecommons.org/licenses/by/3.0/). 